PRACE GEOGRAFICZNE

zeszyt $155,2018,157-172$

doi: $10.4467 / 20833113$ PG.18.019.9542

Instytut Geografii i Gospodarki Przestrzennej UJ

Wydawnictwo Uniwersytetu Jagiellońskiego

\title{
SEDYMENTACJA MAD WIŚLANYCH W TYŃCU
}

\author{
Jacek B. Szmańda, Edyta Łokas, Præemystaw Wachniew, Anna Michno, \\ Tomasz Kalicki, Piotr Swwarczewski, Krzysztof R. Przegietta, \\ Barbara Radwanek-Bak
}

\section{Sedimentation of the Vistula overbank deposits at Tyniec}

Abstract: The study area is located in the gorge section of the Upper Vistula river valley between Tyniec and Piekary near Kraków, where natural and industrial overbank alluvia with a different radionuclide activity, heavy metals content and grain size composition occur. Overbank deposits cover three levels of the floodplain where three cores of deposits were collected. Alluvia of the lowest level along the channel are more heterogeneous and coarser than those on the middle and the highest level. Most of the overbank deposits were accumulated in the lower regime of water flow. On the basis of luminescence dating it was determined that the accumulation of overbank deposits on the first level started 200 years ago and on the highest level $-3,000$ years ago.

All the three alluvium cores investigated in this study show a similar and regular vertical pattern of ${ }^{137} \mathrm{Cs}$ and ${ }^{210} \mathrm{~Pb}$ activity. The vertical distribution of ${ }^{137} \mathrm{Cs}$ in the profiles reflects its postdepositional migration and soil mixing due to ploughing. At the same time the vertical distribution of ${ }^{210} \mathrm{~Pb}$ seems not to be disturbed by this process. Moreover, the peaks of ${ }^{137} \mathrm{Cs}$ are concomitant with a decrease in heavy metal concentration in the top part of all profiles. This reflects the diminishing of industrial activity in Poland after the early 80 's of the $20^{\text {th }}$ century. The vertical profile of ${ }^{210} \mathrm{~Pb}$ activity in the two cores from the upper levels of the floodplain wasused for the estimation of accumulation rates which occur to be approximately $0.4 \mathrm{~cm} /$ year. The vertical differentiation of heavy metals concentration in these profiles reflects both the economic changes in this region over the last century as well as the fluvial activity of the Vistula river. The higher pollution in the upper parts of the two profiles can be correlated with the industrial period which began at the end of the $19^{\text {th }}$ century and lasted up to the middle of the $20^{\text {th }}$ century in the upper Vistula river basin (Silesian Upland and Kraków Upland). The decrease of pollution at the top of all the profiles have results from economic recession and pro-ecological activities since the 1990's. 
Keywords: lithology of overbank deposits, luminescence dating, radionuclide activity, deposition rate, heavy metals concentration, floodplain, upper Vistula river valley

Zarys treści: Obszar badań jest położony w przełomie doliny górnej Wisły pomiędzy Tyńcem a Piekarami pod Krakowem, gdzie znajdują się naturalne i przemysłowe aluwia pozakorytowe (mady), w których badano uziarnienie, aktywności radionuklidów i zawartość metali ciężkich. Mady znajdują się na trzech poziomach równiny zalewowej, z każdego z nich pobrano jeden rdzeń osadów. Aluwia na najniższym poziomie są najgrubsze i niejednorodne w porównaniu z madami zdeponowanymi na dwóch wyższych poziomach. Większość aluwiów była deponowana w warunkach dolnego ustroju przepływu. Na podstawie datowań luminescencyjnych określono, że akumulacja mad na najniższym poziomie rozpoczęła się 200 lat temu, a na najwyższym 3 tys. lat temu.

We wszystkich trzech badanych rdzeniach aluwiów stwierdzono podobny i regularny przebieg aktywności ${ }^{137} \mathrm{Cs}$ i ${ }^{210} \mathrm{~Pb}$. Rozkład pionowy ${ }^{137} \mathrm{Cs}$ odzwierciedla jego migrację w głąb i mieszanie gleby w wyniku orki. Jednocześnie wydaje się, że ten proces nie zakłóca pionowego rozkładu ${ }^{210} \mathrm{~Pb}$. Ponadto, wyraźne piki aktywności ${ }^{137} \mathrm{Cs}$ korelują ze zmniejszeniem stężenia metali ciężkich w górnej części wszystkich profili. Ukazuje to kryzys przemysłowy w Polsce z początku lat 80 . XX w. Profil pionowy aktywności ${ }^{210} \mathrm{~Pb}$ w dwóch rdzeniach z górnych poziomów terasy zalewowej wykorzystano do oszacowania tempa akumulacji, które wynosi około $0,4 \mathrm{~cm} / \mathrm{rok}$.

Pionowe zróżnicowanie koncentracji metali ciężkich w profilach przedstawia zarówno zmiany ekonomiczne w tym regionie w ciągu ostatniego stulecia, jak i natężenie akumulacji aluwiów Wisły. Wyższe zanieczyszczenie w górnej części dwóch profili pobranych z wyższych poziomów można skorelować z okresem przemysłowym, który w dorzeczu górnej Wisły (Wyżyny Śląska i Wyżyny Krakowsko-Częstochowskiej) rozpoczął się pod koniec XIX w. i trwał do połowy XX w. Obniżenie skażenia mad w stropie wszystkich profili jest spowodowane kryzysem gospodarczym i działaniami proekologicznymi od końca lat 80 . XX w.

Stowa kluczowe: litologia mad, datowanie luminescencyjne, aktywność radioizotopów, tempo sedymentacji, koncentracja metali ciężkich, równina zalewowa, dolina górnej Wisły

\section{Wprowadzenie}

Wiek i litologia aluwiów pozakorytowych Wisły w Bramie Krakowskiej były badane przez Rutkowskiego (1986a, b, 1987). Na podstawie wyników jego badań w geomorfologii dna doliny można wyróżnić dwa poziomy terasowe. Poziom wyższy tzw. terasy „rędzinnej” wznoszący się 4-6 m powyżej średniego poziomu wody w korycie Wisły oraz poziom niższy, terasy „łęgowej”, położony na wysokości 2,5-3,0 m ponad średni poziom wody w rzece. Terasa „rędzinna” formowana była w kilku różnowiekowych fazach wydzielonych na podstawie oznaczenia wieku wypełnień mineralno-biogenicznych trzech generacji paleokoryt metodą radiowęglową. Paleokoryta I generacji, o dużych promieniach meandrów, powstały najprawdopodobniej w okresie od młodszego driasu do okresu preborealnego, natomiast małopromienne 
paleokoryta II generacji zostały uformowane w okresie od atlantyku po subatlantyk. Od okresu subatlantyckiego do XVII w. formowane były wielkopromienne paleokoryta III generacji. Współczesny pas meandrowy terasy „łęgowej” zbudowany jest z piaszczystych mad przemysłowych, których nazwa pochodzi od znacznego zanieczyszczenia pyłem węglowym i kilkadziesiąt razy większą niż mad naturalnych (mady terasy „rędzinnej”) zawartością metali ciężkich (Helios-Rybicka 1983; Rutkowski 1986a, b). Aluwia pozakorytowe zalegają na żwirowych i piaszczystych aluwiach korytowych (Rutkowski 1987).

Badania litologii i koncentracji metali ciężkich w aluwiach pozakorytowych Wisły w Tyńcu prowadzili także Klimek i Zawilińska (1985) oraz Macklin i Klimek (1992). W Tyńcu wyróżnili trzy poziomy równiny zalewowej. Najwyższy (poziom III) zbudowany jest z jednorodnych osadów mułkowych zwykle o strukturze masywnej z miejscami słabo zaznaczającą się laminacją horyzontalną. Poziom ten powstał przed 1800 r. Niższy poziom (poziom II) zbudowany z laminowanych horyzontalnie osadów mułkowo-piaszczystych powstał po 1900 r. Najniższy współczesny (uformowany po 1988 r.) poziom inicjalny (kilku centymetrowej miąższości) zbudowany jest z aluwiów drobnoziarnistych akumulowanych w korycie Wisły. Macklin i Klimek (1992) skupili się na analizach zanieczyszczenia mad metalami ciężkimi, nie rozważając szczegółowo ich uziarnienia. Na podstawie badań zmienności zawartości kadmu, cynku i ołowiu we wspominanych aluwiach stwierdzili największe zanieczyszczenie mad w drugim poziomie, występujące na głębokości około 0,5 m poniżej stropu. Najwyższą koncentrację metali wiązali z rozwojem przemysłu w latach 50.-60. XX w.

Cechy uziarnienia aluwiów Wisły w Bramie Krakowskiej zostały opisane przez Rutkowskiego (1987) na podstawie badań 31 próbek, z których 13 pochodziło z mad i wypełnień odciętych koryt rzeki. Dane te stanowiły podstawę do wnioskowania o teksturze badanych osadów. Natomiast informacje o strukturze aluwiów dotyczą wyłącznie aluwiów korytowych w oparciu o profil w Kątach, położony około 1,5 km z biegiem Wisły od Tyńca. Dane te są niewystarczające do szczegółowej charakterystyki litologicznej badanych aluwiów pozakorytowych Wisły. Ponadto wiek osadów określono wyłącznie na podstawie badań radiowęglowych. Dlatego celem przeprowadzonych badań było uszczegółowienie informacji na temat cech litofacjalnych aluwiów pozakorytowych oraz uzupełnienie danych dotyczących czasu akumulacji mad przy użyciu datowań luminescencyjnych zastosowanych bezpośrednio do osadów mineralnych oraz określenia tempa ich depozycji na podstawie badań aktywności radionuklidów. Ponadto w celu zbadania stopnia zanieczyszczenia aluwiów pozakorytowych Wisły koło Tyńca i jego zmian szczególnie w okresie ostatnich 20 lat zostały przeprowadzone analizy koncentracji wybranych pierwiastków śladowych. 


\section{Obszar, zakres i metody badań}

Badania prowadzono w najwęższym ( $0,3 \mathrm{~km}$ szerokości) fragmencie równiny zalewowej w Bramie Krakowskiej pomiędzy Tyńcem i Rybakami (ryc. 1). Brama Krakowska jest wysuniętym najbardziej na południe regionem Wyżyny Krakowskiej, który kontaktuje się z Karpatami (Klimaszewski 1972). Główne elementy jej rzeźby stanowią zręby i rowy tektoniczne. Zręby budują przede wszystkim wapienie jurajskie i kredowe margle. Obniżenia tektoniczne wypełnione są iłami mioceńskimi przykrytymi przez piaszczysto-żwirowe osady wodnolodowcowe (Alexandrowicz 1960; Rutkowski 1987). Wisła tworzy tu odziedziczony przełom epigenetyczny (Gilewska 1972). W rzeźbie równiny zalewowej w przełomie Wisły pomiędzy Tyńcem i Rybakami można wyróżnić trzy poziomy oddzielone krawędziami o wysokości około $2 \mathrm{~m}$ (ryc. 1). W każdym z tych poziomów wykonano sondowanie mechanicznie, pobierając osady o nienaruszonej strukturze. Poziom pierwszy, najniższy, przylega do koryta i ciągnie się wzdłuż niego, tworząc współczesny pas meandrowy. W poziomie tym, w wale przykorytowym, wykonano pierwsze sondowanie (Tyn 1). Poziom drugi stanowi listwę o maksymalnej szerokości około 100 m i długości około 500 m. Rdzeń osadów w tym poziomie (Tyn 2) pobrano z basenu powodziowego pod krawędzią oddzielającą go od poziomu trzeciego. Najwyższy poziom terasowy ma wyrównaną, płaską powierzchnię, z której w miejscu współcześnie nieużytkowanym rolniczo pobrano trzeci profil osadów (Tyn 3).

Zlewnia Wisły w Tyńcu ma powierzchnię 7,5 tys. $\mathrm{km}^{2}$. W jej obrębie znajdują się uprzemysłowione obszary Górnego Śląska, co ma istotny wpływ na zanieczyszczenie aluwiów metalami ciężkimi. Ich dystrybucja odbywa się na równinie zalewowej podczas maksymalnych przepływów $2310 \mathrm{~m}^{3} / \mathrm{s}$ (Punzet 1981) i stanów wody dochodzących do $880 \mathrm{~cm}$ (Soja, Mrozek 1990). Koryto rzeki jest uregulowane. Wisła po regulacji wcięła się o 3 metry, w okresie od lat 70. XIX w. do roku 1954 (Trafas 1975), w którym wybudowano stopień wodny Dąbie (Punzet 1981). Obecnie w korycie Wisły w Tyńcu utrzymuje się stan zbliżony do pełnokorytowego, ponieważ znajduje się ono w obrębie cofki. Powstała ona po spiętrzeniu wód Wisły o 3,7 metra po oddaniu do użytku w 1990 r. stopnia Kościuszko. Stopień ten znajduje się 2 km z biegiem Wisły poniżej Tyńca.

$Z$ rdzeni osadów pobrano próbki aluwiów do analiz laboratoryjnych. Analizy uziarnienia wykonano w Laboratorium Geomorfologicznym Instytutu Geografii i Gospodarki Przestrzennej Uniwersytetu Jagiellońskiego w Krakowie. Na podstawie wyników badań uziarnienia wyliczono wskaźniki statystyczne metodą momentów centralnych w programie Gradistat. Datowanie luminescencyjne trzech próbek mad pobranych z profili - pierwszego - Tyn 1 (1 próbka) i drugiego - Tyn 2 (2 próbki) (ryc. 2) prowadzono we współpracy z Laboratorium Datowania w Risø przy Uniwersytecie w Åarhus (Dania). Aktywność ${ }^{137}$ Cs została określona na podstawie linii 
promieniowania gamma o energii $662 \mathrm{keV}$. Pomiary przeprowadzono na spektrometrze gamma zgodnie z akredytowaną przez PCA procedurą (AB 979). Oznaczenia aktywności ${ }^{137}$ Cs zostały wykonane w Pracowni Badań Skażeń Radioaktywnych Środowiska Instytutu Fizyki Jądrowej PAN w Krakowie. Analizy aktywności izotopu ${ }^{210} \mathrm{~Pb}$ zostały przeprowadzone na Wydziale Fizyki i Informatyki Stosowanej Akademii Górniczo-Hutniczej w Krakowie. Aktywnośc ${ }^{210} \mathrm{~Pb}$ wyznaczono poprzez pomiar aktywności ${ }^{210} \mathrm{Po}$, który jest produktem rozpadu promieniotwórczego ${ }^{210} \mathrm{~Pb}$. Po analizie aktywności ${ }^{137} \mathrm{Cs}, 1-2 \mathrm{~g}$ próbki zostały zmineralizowane przy użyciu $\mathrm{HNO}_{3}$ $\mathrm{i}_{2} \mathrm{O}_{2}$. Izotop ${ }^{210} \mathrm{Po}$ wydzielono z roztworu poprzez spontaniczną elektrodepozycję na srebrnych krążkach. Wydajność odzysku polonu w stosowanych procedurach chemicznych określono przy użyciu znacznika ${ }^{208}$ Po. Pomiar został wykonany na spektrometrze alfa (Canberra S570). Analizy koncentracji metali ciężkich (Cd, Cr, $\mathrm{Cu}, \mathrm{Ni}, \mathrm{Pb}, \mathrm{Zn}$ ) były wykonywane we frakcji mułkowej i ilastej, przesianej przez nylonowe sito o średnicy $0,063 \mathrm{~mm}$, metodą Spektrometrii Fluorescencji Rentgenowskiej (XRF) w Centralnym Laboratorium Chemicznym Państwowego Instytutu Geologicznego w Warszawie.

\section{Litologia i warunki sedymentacji mad}

Litologia mad została rozpoznana na podstawie analiz litofacjalnych i analizy uziarnienia. Aluwia pozakorytowe pobrane w trzech profilach różnią się zarówno pod względem uziarnienia, jak i struktury.

W profilu pierwszym (Tyn 1) pobranym z wału przykorytowego na najniższym poziomie stwierdzono głównie osady piaszczyste i piaszczysto mułkowe ( $\mathrm{Mz}-$ 3,6 phi, zakres: 1,5-6,0 phi) o strukturze masywnej lub warstwowaniu horyzontalnym (ryc. 2A). Na uwagę zasługuje warstwa diamiktonu powodziowego o zwartym szkielecie ziarnowym (Dm), znajdująca się na głębokości 25-45 cm. W warstwie tej występują ziarna żwiru o średnicy około $6 \mathrm{~cm}$, których udział sięga 10\%. Prawdopodobnie depozycja osadów diamiktonowych odbywała się w warunkach wysoko skoncentrowanych przepływów pozakorytowych, w których transport osadu miał charakter plastyczno-lepkiego płynięcia typu spływu gęstościowego. Miąższość mad w tym profilu osiąga $1,15 \mathrm{~m}$.

Profil drugi (Tyn 2) pobrano na drugim poziomie z basenu powodziowego. Miąższość mad osiąga w nim $2 \mathrm{~m}$ (ryc. 2B). Są to przede wszystkim mułki (średnia $\mathrm{Mz}-6,4$ phi, zakres: 5,4-7,4 phi) masywne lub mułki warstwowane rytmicznie. Rytmika powodziowa w mułkach może stanowić zapis wznoszenia i opadania fali powodziowej (Szmańda 2006). Jednak, jak uważa Teisseyre (1988), laminacja horyzontalna w mułkach może także być cyklotemalnym zapisem wnoszenia i opadania wody podczas wezbrania pozakorytowego, w postaci zestawu lamin składającego 
się z trzech lamin: (1) mułku masywnego, (2) mułku laminowanego riplemarkowo i (3) mułku masywnego (Teisseyre 1988; Szmańda 2011). Należy podkreślić, że poza warstwą piasków znajdującą się na głębokości 1,83-1,85 m aluwia w profilu tym powstawały w warunkach mniej energetycznych przepływów wody niż mady w profilu pierwszym.

W pobranym z powierzchni najwyższego poziomu trzecim profilu (Tyn 3) stwierdzono podobną jak w profilu Tyn 2 miąższość mad sięgającą około 2 m (ryc. 2C). Aluwia pozakorytowe w profilu tym wykształcone są głównie w postaci piasków mułkowych lub mułków piaszczystych (średnie Mz - 4,4 phi, zakres: 3,0-6,4 phi) o strukturze masywnej. W stropie tego profilu znajduje się warstwa masywnych piasków żwirowych, w których udział frakcji żwirowej o rozmiarach ziaren 2,0-4,8 cm wynosi $38 \%$.

Analizowane aluwia pozakorytowe charakteryzują się ogólnie dużym zróżnicowaniem uziarnienia, od osadów gruboziarnistych typu diamiktonu powodziowego i piasku żwirowego po drobnoklastyczne mułki. Osady te są słabo albo bardzo słabo wysortowane (ryc. 3). Przy czym najsłabiej wysortowane są osady piaszczysto-mułkowe w profilu Tyn 3, a najlepiej aluwia mułkowe w profilu Tyn 2. Analizując rozmieszczenie próbek osadów na diagramie średniej średnicy ziarna i wysortowania (ryc. 3) oraz diagramie zależności skośności i kurtozy (ryc. 4), na podstawie poglądów Sly i in. (1983) należy uznać, że były one w większości akumulowane w warunkach dolnego ustroju przepływu.

\section{Datowanie luminescencyjne}

Datowanie luminescencyjne jest od połowy lat 90. ubiegłego wieku z powodzeniem stosowane w badaniach wieku osadów rzecznych (Murray i in. 1995; Wallinga 2002), w tym aluwiów pozakorytowych (Preusser 1999; Gębica 2004; Szmańda i in. 2004; Kunz i in. 2014). Dla osadów deponowanych w środowisku wodnym problemem może być zjawisko niedostatecznego wygaszenia luminescencji (Weckwerth i in. 2013). Wiek badanych aluwiów oznaczono metodą optycznie stymulowanej luminescencji (OSL) w trzech próbkach pobranych z profili Tyn 1 i Tyn 2 (ryc. 2), gdyż metoda OSL jest znacznie mniej wrażliwa na efekt niedostatecznego wygaszenia niż stosowana wcześniej termoluminescencja (Oczkowski i in. 1998). W profilu Tyn 1 w próbce piasków średnio- i drobnoziarnistych, warstwowanych horyzontalnie, pobranych z głębokości $150 \mathrm{~cm}$ (OSL 1, ryc. 2A), czas depozycji określono na 230-190 lat temu. Próbka ta została pobrana ze stropu osadów korytowych. W profilu Tyn 2 oznaczono wiek depozycji w dwóch próbkach aluwiów. Wiek pierwszej z nich, pobranej na głębokości $185 \mathrm{~cm}$ z warstwy masywnych piasków drobnoziarnistych (OSL 2, ryc. 2B), określono na 3,05-2,69 tys. lat temu. Była to próbka 


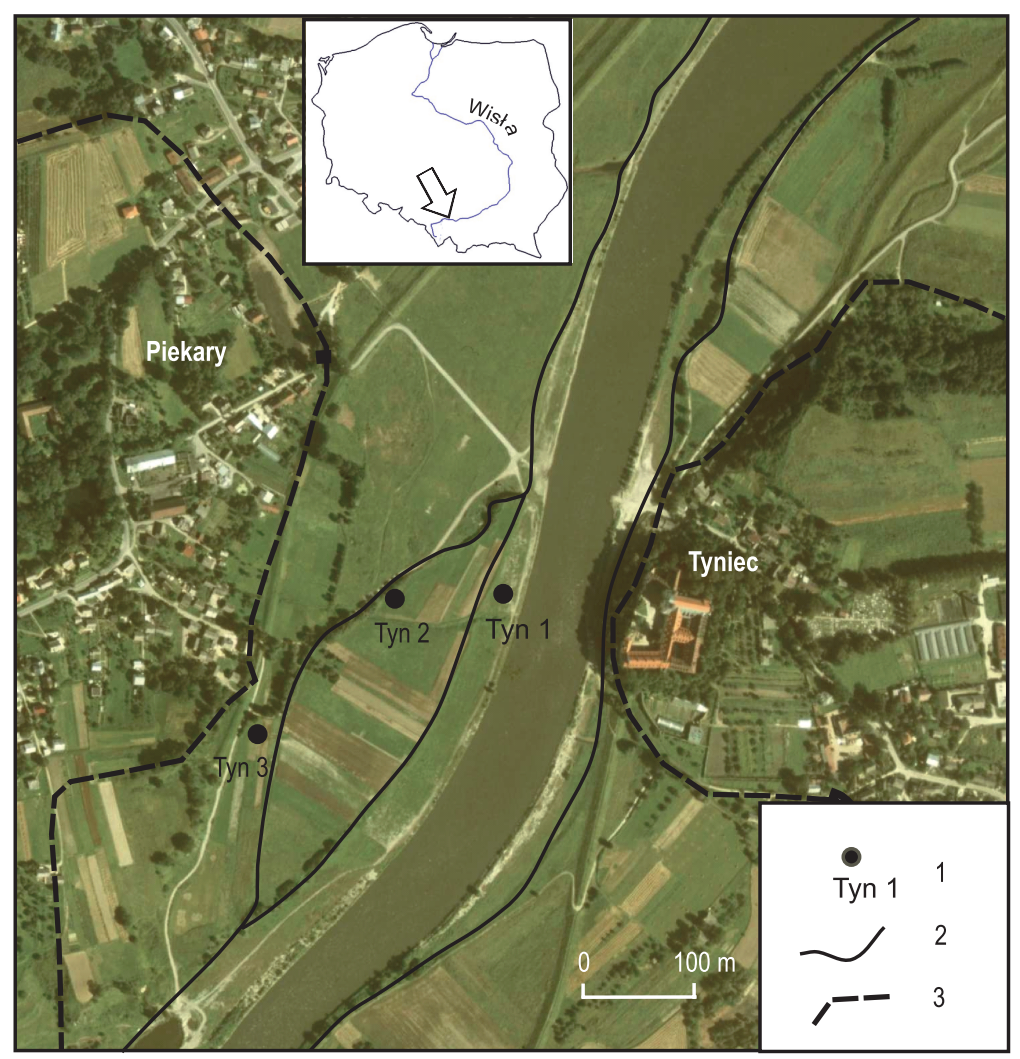

Ryc. 1. Dolina Wisły - równina zalewowa w Bramie Krakowskiej pomiędzy Tyńcem i Piekarami Fig. 1. Vistula river valley - floodplain in the Kraków Gate between Tyniec and Piekary

Objaśnienia: 1 - lokalizacja profili, 2 - krawędzie poziomów terasowych, 3 - krawędzie zrębów tektonicznych zbudowanych z wapieni jurajskich.

Explanations: 1 - location of profiles, 2 - edges of floodplain levels, 3 - edges of horst hills built of Jurassic limestone. 


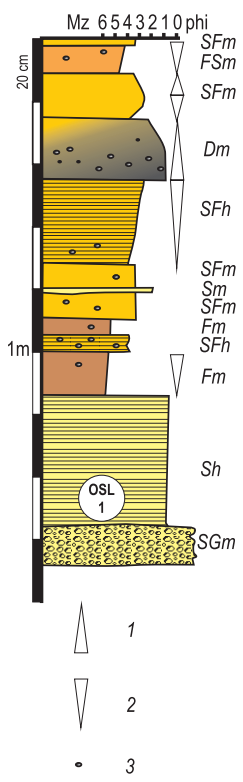

A

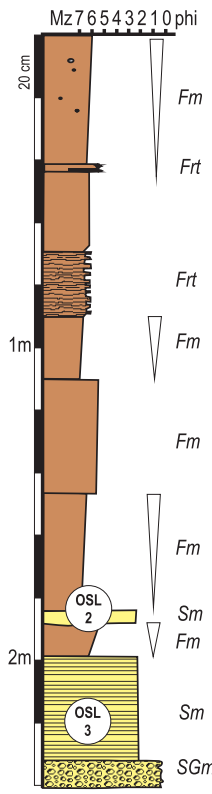

B

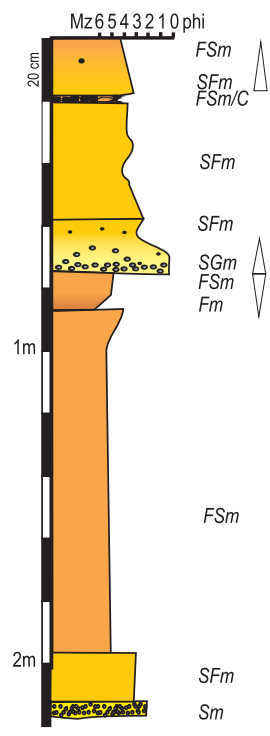

C

Ryc. 2. Profile litofacjalne aluwiów pozakorytowych Wisły w Tyńcu

Fig. 2. Lithofacial profiles of overbank alluvia of Vistula river at Tyniec

Objaśnienia: A - profil Tyn 1, B - profil Tyn 2, C - profil Tyn 3;

1 - drobnienie frakcji ku górze, 2 - grubienie frakcji ku górze, 3 - ziarna żwirowe;

Dm - diamikton masywny, SGm - piasek żwirowy masywny, Sm - piasek masywny, Sh - piasek laminowany poziomo, SFm - piasek mułkowy masywny, SFh - piasek mułkowy laminowany poziomo, FSm - mułek piaszczysty masywny, Fm - mułek masywny, Fr - rytmit mułkowy, C - materia organiczna. Explanations: A - profile Tyn 1, B - profile Tyn 2, C-profile Tyn 3;

1 - decrease in grain size upwards, 2 - increase in grain size upwards, 3 - gravel grains;

$\mathrm{Dm}$ - massive diamicton, SGm - massive gravelly sand, Sm - massive sand, Sh - horyzontally laminated sand, SFm - massive silty sand, SFh - horyzontally laminated silty sand, FSm - massive sandy silt, Fm - massive silt, Fr - rythmically laminated silt, $\mathrm{C}$ - organic matter. 


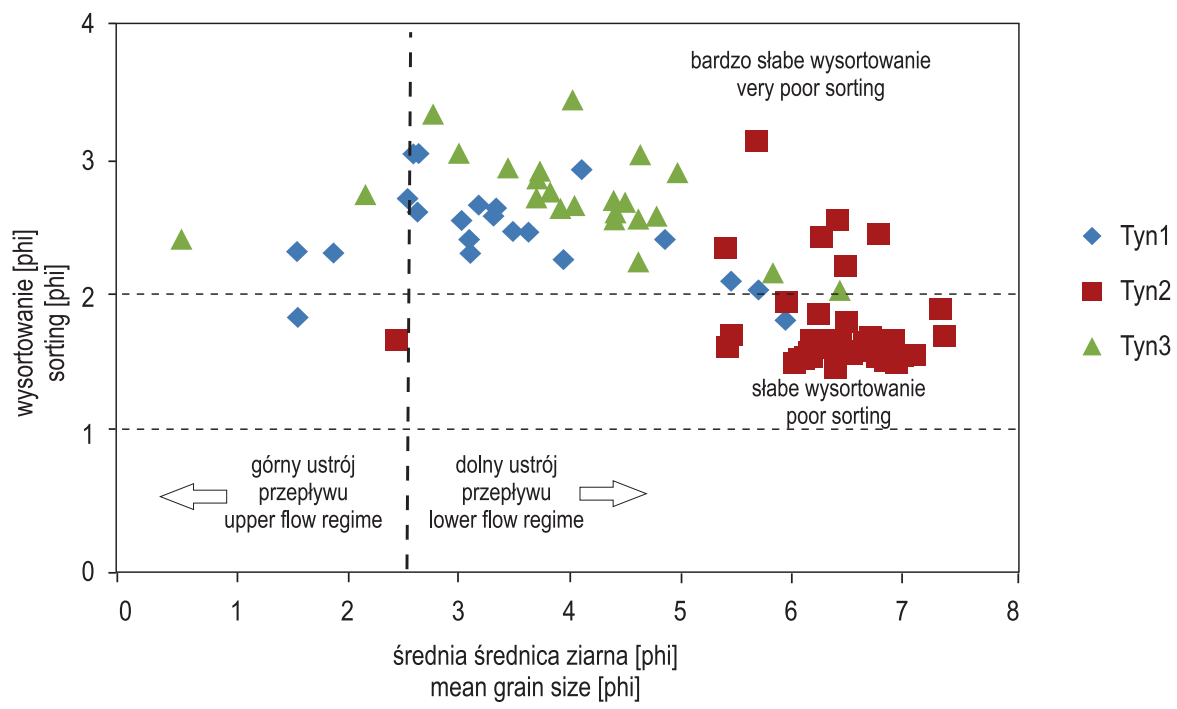

Ryc. 3. Rozkład próbek aluwiów pozakorytowych na diagramie zależności średniej średnicy ziarna i wysortowania

Fig. 3. Distribution of overbank alluvia samples on a diagram depicting the mean grain size versus sorting

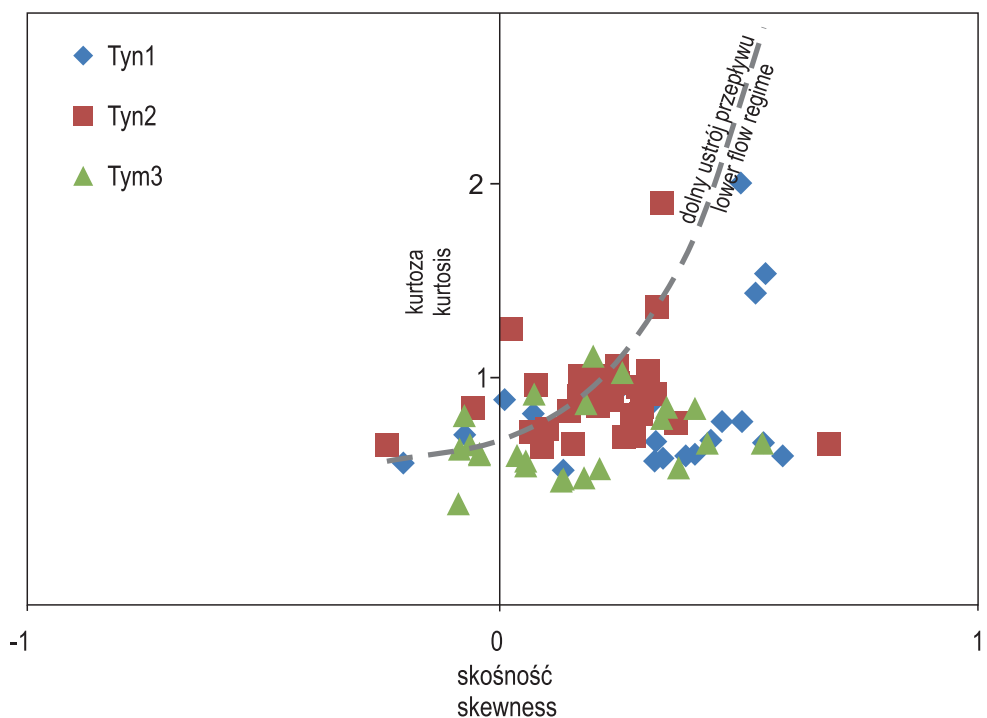

Ryc. 4. Rozkład próbek aluwiów pozakorytowych na diagramie zależności skośności i kurtozy Fig. 4. Distribution of overbank alluvia samples on a diagram depicting skewness versus kurtosis 

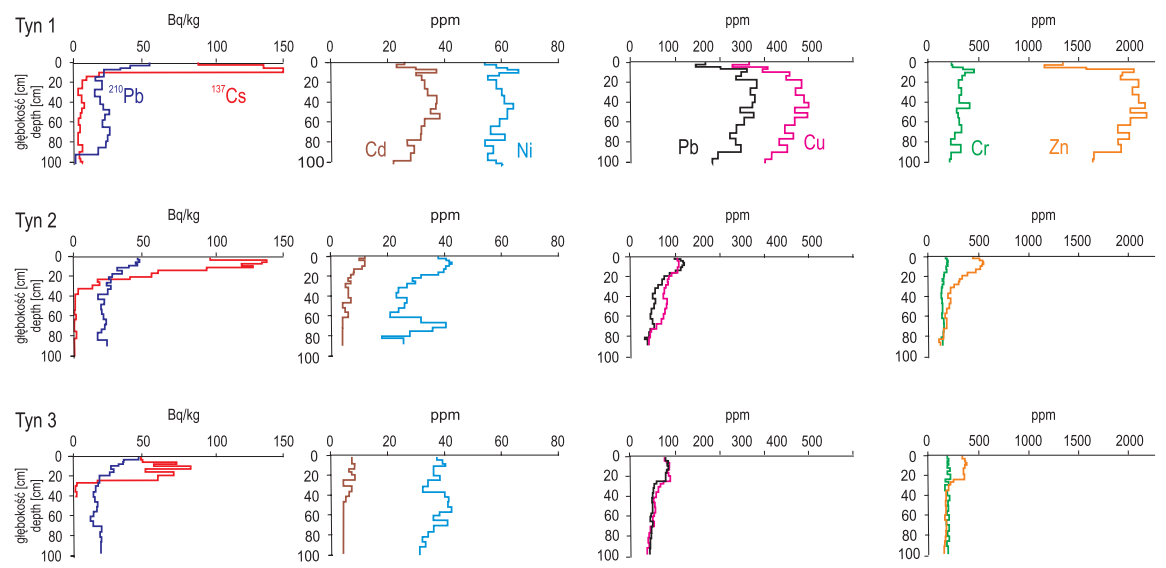

Ryc. 5. Pionowa zmienność aktywności ${ }^{137} \mathrm{Cs}$ i ${ }^{210} \mathrm{~Pb}$ oraz koncentracji metali ciężkich Fig. 5. Vertical changeability of ${ }^{137} \mathrm{Cs}$ and ${ }^{210} \mathrm{~Pb}$ activity and heavy metals concentration
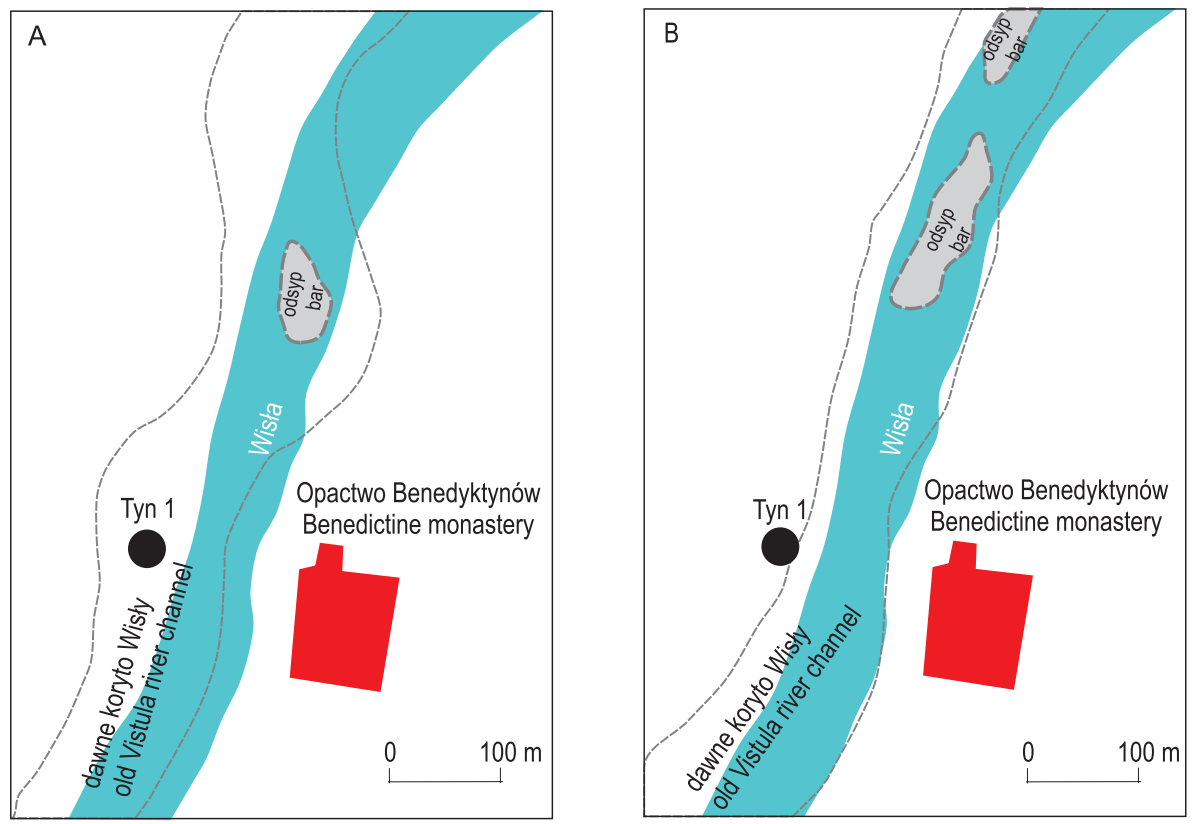

Ryc. 6. Dawne położenie koryta Wisły względem współczesnego i profilu Tyn 1 (w oparciu o dane z http://mapire.eu/en/)

Fig. 6. Former location of the Vistula river channel in relation to the contemporary and Tyn 1 profile (based on date from http://mapire.eu/en/) Objaśnienia: A - w latach 1779-1793, B - 1806-1869

Explanations: A - in the years 1779-1793, B - in the years 1806-1869 


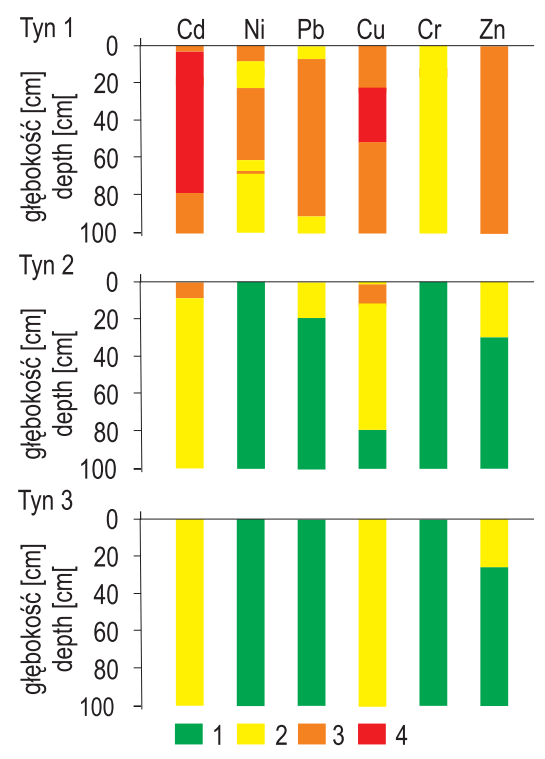

Ryc. 7. Indeks geoakumulacji metali ciężkich w aluwiach pozakorytowych w profilach Tyn 1, Tyn 2, Tyn 3

Fig. 7. Geoaccumulation index of heavy metals of overbank alluvia in profiles Tyn 1, Tyn 2, Tyn 3

Objaśnienia: mady 1 - niezanieczyszczone, 2 - umiarkowanie zanieczyszczone, 3 - wysoko zanieczyszczone, 4 - ponadnormatywne.

Explanations: overbank deposits 1 - unpolluted, 2 - moderately polluted, 3 - highly polluted, 4 - polluted above limits. 
mady. Natomiast wiek stropu aluwiów korytowych w próbce masywnych piasków drobnoziarnistych pobranych z głębokości $230 \mathrm{~cm}$ (OSL 3, ryc. 2B) oznaczono na 3,49-3,03 tys. lat temu. Na podstawie uzyskanych datowań można stwierdzić, że aluwia pozakorytowe na najniższym poziomie równiny zalewowej, w obrębie wału przykorytowego, były akumulowane w czasie ostatnich około 200 lat. Natomiast mady na drugim poziomie równiny zalewowej powstawały od około 3 tys. lat temu. Czasu depozycji aluwiów pozakorytowych na najwyższym poziomie nie określono.

\section{Koncentracja radioizotopów ${ }^{137} \mathrm{Cs}$ i ${ }^{210} \mathrm{~Pb}$}

Badania koncentracji radionuklidów w madach jest pomocne w określaniu ich wieku, tempa depozycji i wpływu działalności antropogenicznej na ich akumulację (He, Walling 1996; Walling, He 1997, 1999; Korobova i in. 2008; Ciszewski, Czajka 2009; Łokas i in. 2019). Analizy koncentracji izotopów ${ }^{137} \mathrm{Cs}$ i ${ }^{210} \mathrm{~Pb}$ przeprowadzono we wszystkich trzech badanych profilach do głębokości $1 \mathrm{~m}$.

Profile aktywności ${ }^{137} \mathrm{Cs}$ przedstawiono na ryc. 5. Wysoką aktywność tego radionuklidu stwierdzono w profilu Tyn 1 do głębokości $13 \mathrm{~cm}(18 \mathrm{~Bq} / \mathrm{kg})$, ale wykrywalność tego radionuklidu w zakresie od $3 \mathrm{~Bq} / \mathrm{kg}$ do $11 \mathrm{~Bq} / \mathrm{kg}$ została zarejestrowana także w dolnej części profilu. Bardzo wyraźny pik aktywności ${ }^{137} \mathrm{Cs}$ (około $150 \mathrm{~Bq} / \mathrm{kg}$ ) występuje na głębokości $7 \mathrm{~cm}$. W pozostałych dwóch profilach ${ }^{137} \mathrm{Cs}$ jest prawie całkowicie zawarty w stropowej części do głębokości $30 \mathrm{~cm}$ (kilkanaście Bq/kg). Maksimum aktywności tego izotopu w profilu Tyn 2 wynosi $137 \mathrm{~Bq} / \mathrm{kg}$ (na głębokości $4 \mathrm{~cm}$ ), natomiast w profilu Tyn 3 wynosi $82 \mathrm{~Bq} / \mathrm{kg}$ na głębokości $13 \mathrm{~cm}$. W profilu Tyn 2 stwierdzono wyraźne dwa piki aktywności, a w profilu Tyn 3 trzy piki. W rdzeniu Tyn 2 pik na głębokości $4 \mathrm{~cm}$ jest związany z katastrofą elektrowni w Czarnobylu, natomiast pik na głębokości $10 \mathrm{~cm} \mathrm{z}$ próbnymi wybuchami atomowymi w latach 50. Obecność trzech pików aktywności w rdzeniu Tyn 3 wynika z przemieszania górnej części profilu gleby poprzez zabiegi agrotechniczne (orkę). W profilu Tyn 2 od głębokości $30 \mathrm{~cm}$ aktywnośc ${ }^{137} \mathrm{Cs}$ spada do poziomu od $3 \mathrm{~Bq} / \mathrm{kg}$ do $0,2 \mathrm{~Bq} / \mathrm{kg}$. W profilu Tyn 3 na głębokości $40 \mathrm{~cm}$ zanika całkowicie. Średnie zasoby ${ }^{137} \mathrm{Cs}$ w profilach Tyn 1 , Tyn 2 i Tyn 3 wynoszą odpowiednio: $20,1 \mathrm{kBq} / \mathrm{m}^{2}$, $22,6 \mathrm{kBq} / \mathrm{m}^{2}$ i $17,4 \mathrm{kBq} / \mathrm{m}^{2}$.

Profile aktywności ${ }^{210} \mathrm{~Pb}$ mają podobne do siebie kształty (ryc. 5), z monotonicznym, ale dość szybkim, spadkiem od $55 \mathrm{~Bq} / \mathrm{kg}$ (Tyn 1) i 45 Bq/kg (Tyn 2 i 3) przy powierzchni do około $26 \mathrm{~Bq} / \mathrm{kg}$ na głębokości $10 \mathrm{~cm}$ ('Tỳn 1), $25 \mathrm{~cm}$ ('Tỳn 2) i $30 \mathrm{~cm}$ (Tyn 3). W profilach Tyn 2 poniżej $25 \mathrm{~cm}$ głębokości aktywność ${ }^{210} \mathrm{~Pb}$ waha się wokół wartości $20 \mathrm{~Bq} / \mathrm{kg}$. Ten poziom aktywności uznano za reprezentujący autochtoniczną pozostałość badanego radioizotopu ołowiu. Natomiast w profilach Tyn 1 i Tyn 3 aktywność ${ }^{210} \mathrm{~Pb}$ po spadku do $16 \mathrm{~Bq} / \mathrm{kg}$ (na głębokości $32 \mathrm{~cm}$ w profilu Tyn 1) 
i $11 \mathrm{~Bq} / \mathrm{kg}$ (na głębokości $64 \mathrm{~cm}$ w profilu Tyn 3) wzrasta w dolnej części rdzeni, przy czym w profilu Tyn 1 osiąga wartości bliskie zmierzonym w najwyższych warstwach, co czyni ten profil nieodpowiednim do oszacowania tempa akumulacji. Pomimo nieznacznego wzrostu aktywności radioizotopu ołowiu w spągu profilu Tyn 3, profile allogenicznego ${ }^{210} \mathrm{~Pb}$ Tyn 2 i Tyn 3 są bardzo podobne do siebie, a odpowiednie stężenia powierzchniowe allogenicznego ${ }^{210} \mathrm{~Pb}$ wynoszą $0,43 \mathrm{~Bq} / \mathrm{cm}^{2}$ i $0,44 \mathrm{~Bq} / \mathrm{cm}^{2}$. Stężenia powierzchniowe ${ }^{210} \mathrm{~Pb}$ w pobranych rdzeniach mad są znacznie wyższe od stężenia ${ }^{210} \mathrm{~Pb}$ w rdzeniu gleby zebranym z nieuprawnej łąki na terenie zawala, w dnie doliny Wisły, blisko miejsca, z którego wydobyto rdzeń Tyn 3. Poziom aktywności ${ }^{210} \mathrm{~Pb}$ w pobranym rdzeniu gleby reprezentuje depozycję atmosferyczną ${ }^{210} \mathrm{~Pb}$ o wielkości $0,2 \mathrm{~Bq} / \mathrm{cm}^{2}$. Badane aluwia pozakorytowe Wisły mają zatem znaczący składnik ${ }^{210} \mathrm{~Pb}$, który nie jest związany z bezpośrednią depozycją z atmosfery i można go wykorzystać do oszacowania tempa akumulacji mad, co wykonano na podstawie dwóch profili Tyn 2 i Tyn 3.

\section{Koncentracja metali ciężkich}

Koncentrację metali ciężkich badano, podobnie jak w przypadku aktywności radionuklidów, w próbkach pobranych w badanych profilach do głębokości $1 \mathrm{~m}$. Różnice w koncentracji badanych pierwiastków śladowych (Cd, Cr, $\mathrm{Cu}, \mathrm{Ni}, \mathrm{Pb}$, Zn) pomiędzy profilami i jej zróżnicowanie pionowe można prześledzić na ryc. 5. Koncentracja metali ciężkich jest znacznie wyższa w profilu Tyn 1 niż w profilach Tyn 2 i 3, która w tych profilach jest na podobnym poziomie. Koncentracja cynku jest wyższa średnio 10 razy, kadmu i miedzi - 7 razy, ołowiu - 4 razy, chromu 4 razy, a niklu - 2 razy. Różnice pomiędzy największą i najmniejszą z zanotowanych wartości stężenia metali ciężkich w badanych profilach wynoszą: $\mathrm{Zn}-68$ razy, $\mathrm{Cu}-33$ razy, $\mathrm{Pb}-18$ razy, $\mathrm{Cd}-18$ razy, $\mathrm{Cr}-9$ razy, $\mathrm{Ni}-4$ razy.

Maksymalne wartości koncentracji badanych metali stwierdzono w profilu Tyn 1 na następujących głębokościach: $10 \mathrm{~cm}$ - Cr (450 ppm) i Ni (66 ppm), $26 \mathrm{~cm}-\mathrm{Pb}$ (280 ppm), 45 cm - Cu (395 ppm) i $55 \mathrm{~cm}$ - Zn (2171 ppm) i Cd (38 ppm). Generalnie stężenie metali ciężkich w tym profilu rośnie od spągu na głębokości około $100 \mathrm{~cm}$ do 40-60 cm, następnie nieznacznie spada na głębokości 15-20 cm, znowu rośnie na głębokości $10 \mathrm{~cm}$ i znowu spada ku powierzchni.

W profilu Tyn 2 stężenie pierwiastków śladowych jest największe w stropie i wynosi maksymalnie na następujących głębokościach: $6 \mathrm{~cm}-\operatorname{Cr}(118 \mathrm{ppm})$, $\mathrm{Pb}(88 \mathrm{ppm})$ i Cd (10 ppm), $8 \mathrm{~cm}-$ Zn (471 ppm), Cu (100 ppm) i Ni (41 ppm). Ogólnie koncentracja badanych metali stopniowo rośnie od spągu do głębokości około $20 \mathrm{~cm}$, następnie wyraźnie wzrasta do maksymalnych wartości na wspominanych wcześniej głębokościach, a wyżej spada ku powierzchni do wartości zbliżonych do 
zanotowanych na głębokości $20 \mathrm{~cm}$. Wyjątkiem jest stężenie niklu, które jest zróżnicowane w zakresie od około 20 ppm do około 40 ppm i rośnie od spągu do głębności $70 \mathrm{~cm}$, wyżej spada do minimalnej notowanej wartości w tym profilu na głębokości $60 \mathrm{~cm}(19 \mathrm{ppm})$, a następnie wykazuje podobny trend jak pozostałe metale.

Zmienność koncentracji metali ciężkich w profilu Tyn 3 jest podobna do stwierdzonej w profilu Tyn 2. Stężenie badanych pierwiastków stopniowo wzrasta ku stropowi, a w przypadku kadmu, ołowiu, cynku i miedzi rośnie dość szybko od głębokości $30 \mathrm{~cm}$ do maksymalnych wartości na głębokości 10-13 cm: Zn - 289 ppm, Cr - 114 ppm, $\mathrm{Cu}$ i $\mathrm{Pb}-65 \mathrm{ppm}, \mathrm{Cd}-6 \mathrm{ppm}$. Koncentracja tych metali nieznacznie spada tuż przy powierzchni od głębokości $6 \mathrm{~cm}$ do wartości zbliżonych do zanotowanych na głębokości $30 \mathrm{~cm}$. Podobnie jak w profilu Tyn 2, w profilu tym inną od pozostałych pierwiastków zmienność w pionie stwierdzono w przypadku niklu, którego koncentracja na głębokości 50-55 cm osiąga maksymalną wartość 40 ppm (por. ryc. 5).

\section{Dyskusja}

Cechy litofacjalne i uziarnienia badanych mad wskazują na zróżnicowane warunki ich akumulacji. Bez wątpienia na zróżnicowanie to miało wpływ miejsce poboru rdzeni. Profil Tyn 1 pobrano ze współczesnego wału przykorytowego, profil Tyn 2 z basenu powodziowego na drugim poziomie zalewowym, a profil Tyn 3 z płaskiej równi zalewowej na najwyższym poziomie (ryc. 1). Najbardziej zróżnicowany litologicznie i strukturalnie jest profil Tyn 1, pobrany z wału przykorytowego, natomiast najbardziej homogeniczny jest profil Tyn 2 z basenu powodziowego (ryc. 2).

W profilu Tyn 1 zostały zarejestrowane przepływy o najbardziej zróżnicowanej energii, spośród wszystkich badanych aluwiów, od masywnych mułków zdeponowanych w warunkach niskoenergetycznych przepływów pozakorytowych po osadzone w warunkach górnego ustroju przepływu osady o średniej średnicy ziarna w zakresie 1,5-2,7 phi (ryc. 3). Aluwia powstałe podczas wysokoenergetycznych przepływów to: (1) znajdująca się na głębokości $90 \mathrm{~cm}$ kilkucentymetrowa warstwa masywnego grubo- i średnioziarnistego piasku, (2) zlegająca na głębokości 25-45 cm warstwa masywnego diamiktonu, który mógł powstać w warunkach przepływów o dużej koncentracji materiału klastycznego, (3) zdeponowana na głębokości około $20 \mathrm{~cm}$ środkowa część warstwy masywnego mułku piaszczystego. Ze względu na stwierdzone w tej warstwie tendencje, najpierw do grubienia, a następnie do drobnienia frakcji w górę (ryc. 2), można przypuszczać, że zostały w niej zarejestrowane, zarówno faza wznoszenia, jak i opadania fali powodziowej. Zatem warstwa ta mogła powstać podczas jednej powodzi.

Wysokoenergetyczne warunki górnego ustroju przepływu zostały także zarejestrowane w profilu Tyn 3 (ryc. 3). Reprezentuje je warstwa masywnych piasków żwirowych 
zalegająca na głębokości 58-75 cm, dla której w spągowej części zanotowano największą średnią średnicę ziarna (0,5 phi) spośród badanych profili. Pozostałe aluwia, czyli masywne mułkowo-piaszczyste i piaszczysto mułkowe mady powstawały w warunkach niskoenergetycznych dolnego ustroju przepływu.

W warunkach przepływów o najniższej energii akumulowane były aluwia w profilu Tyn 2. Niewielkie fluktuacje prędkości przepływu powodziowego zostały zapisane w tym profilu na głębokości 42-46 cm i 70-90 cm w rytmitach mułkowych, w których pozostałością po fazie wznoszenia fali powodziowej są struktury riplemarkowe (Rees 1966; Teisseyre 1988; Szmańda 2011).

Całkowity zasób ${ }^{137} \mathrm{Cs}$ w profilach zmieniał się od $17,4 \mathrm{kBq} / \mathrm{m}^{2}$ do $22,6 \mathrm{kBq} / \mathrm{m}^{2}$. Depozycja ${ }^{137}$ Cs związana z globalnym opadem promieniotwórczym dla Polski wynosi $982 \mathrm{~Bq} / \mathrm{m}^{2}$, natomiast średnia wartość depozycji (łącznie z opadem z Czarnobyla) wynosi $3770 \mathrm{~Bq} / \mathrm{m}^{2}$ (Poręba, Bluszcz 2007). Średnia wartość depozycji dla pozostałych regionów południowej Polski, np. województwo opolskie i katowickie, wynoszą odpowiednio $11,2 \mathrm{kBq} / \mathrm{m}^{2}$ i $6,8 \mathrm{kBq} / \mathrm{m}^{2}$ (Stach, 1996), przy $80 \%$ udziale opadów promieniotwórczych ${ }^{137} \mathrm{Cs}$ z Czarnobyla.

Stwierdzone w badanych profilach depozycje ${ }^{137} \mathrm{Cs}$ zbliżone do wartości z obszaru opolskiego i katowickiego wskazują na znaczny udział ${ }^{137}$ Cs pochodzącego z Czarnobyla w aluwiach pozakorytowych Wisły. Dlatego też maksima obserwowane w badanych profilach, z wyjątkiem profilu Tyn 3, były łączone z 1986 r. Ponieważ najwyższe aktywności ${ }^{137}$ Cs można wiązać z jego emisją w czasie katastrofy elektrowni jądrowej w Czarnobylu, oszacowane tempa akumulacji aluwiów pozakorytowych w Bramie Krakowskiej na podstawie aktywności ${ }^{137} \mathrm{C}$ w profilach pionowych wynoszą 2-3 mm/rok i maleją wraz z odległością od koryta rzeki.

Przydatność ${ }^{210} \mathrm{~Pb}$ do określania tempa akumulacji na równinie zalewowej zależy od wielu czynników, przede wszystkim od regularności depozycji materiału na równinie oraz od znajomości wielkości lokalnego strumienia ${ }^{210} \mathrm{~Pb}$ deponowanego $\mathrm{z}$ atmosfery. Nie zawsze więc możliwe są wiarygodne szacunki tempa akumulacji. Głębokościowe profile ${ }^{210} \mathrm{~Pb} \mathrm{w}$ osadach pozakorytowych pozwalają porównać uwarunkowania akumulacji pozakorytowej pomiędzy różnymi lokalizacjami. Porównanie kształtu profili i wielkości zawartych w nich zasobów ${ }^{210} \mathrm{~Pb}$ pozwala na co najmniej półilościowe porównanie tempa akumulacji oraz na określenie regularności dostawy materiału powodziowego. Ze względu na wzrastający znacznie poziom aktywności ${ }^{210} \mathrm{~Pb}$ w profilach Tyn 1, co może być spowodowane postdepozycyjną mobilnością ${ }^{210} \mathrm{~Pb}$, związaną z płytkim występowaniem wody, wyklucza to zastosowanie metody ${ }^{210} \mathrm{~Pb}$ w przypadku tego profilu. Na podstawie przeprowadzonych badań tempo akumulacji mad udało się oszacować jedynie w profilach Tyn 2 i 3 i wynosi ono 4 mm/rok.

Istotne dane dla ustalenia czasu depozycji badanych mad i rozwoju równiny zalewowej w badanym fragmencie dna doliny Wisły pomiędzy Tyńcem i Rybakami wniosły datowania luminescencyjne. $\mathrm{Na}$ ich podstawie stwierdzono, że akumulacja 
mad na najniższym poziomie zaczęła się około 200 lat temu. Ustalenia te potwierdza analiza zmian układu koryta Wisły na podstawie pierwszego i drugiego wojskowego zdjęcia topograficznego dostępnego na stronie internetowej http://mapire.eu/en/ (ryc. 6). Na tej podstawie stwierdzono, że miejsce poboru profilu Tyn 1 znajdowało się w latach 1779-1793 na pierwszym wojskowym zdjęciu topograficznym, zwanym także józefińskim lub mapą Miega, w środku koryta rzeki (ryc. 1A). Natomiast miejsce to na drugim wojskowym zdjęciu topograficznym, zwanym również franciszkowskim, z lat 1806-1869 znajduje się przy krawędzi koryta Wisły. Początek akumulacji mad w basenie powodziowym na drugim poziomie zalewowym został określony przy pomocy dwóch dat luminescencyjnych, których porządek w profilu Tyn 2 jest logiczny (ryc. 2B). Ponieważ zakres daty warstwy mady piaszczystej z głębokości 1,85 cm, wynoszący - 3,05-2,69 ka (OSL 2, ryc. 2B), i daty uznanych za korytowe masywnych piasków drobnoziarnistych pobranych z głębokości $230 \mathrm{~cm}$ z przedziału -3,49-3,03 ka (OSL 3, ryc. 2B) zachodzą na siebie, przyjęto, że zalegające powyżej tych aluwiów mułki były akumulowane w ciągu ostatnich 3 tys. lat.

Przyjmując oszacowane na podstawie badań aktywności radionuklidów tempo akumulacji mad: ${ }^{137} \mathrm{Cs}-2-3 \mathrm{~mm} / \mathrm{rok}$ i ${ }^{210} \mathrm{~Pb}-4 \mathrm{~mm} / \mathrm{rok}$, należy stwierdzić, że warstwa aluwiów pozakorytowych zakumulowana na poziomie pierwszym przy korycie Wisły powinna w czasie ostatnich 200 lat osiągnąć miąższość od $20 \mathrm{~cm}$ do $80 \mathrm{~cm}$, natomiast seria mułków w basenie powodziowym, na drugim poziomie, powinna w ciągu 3 tys. lat osiągnąć od $6 \mathrm{~m}$ do $12 \mathrm{~m}$. W pierwszym przypadku rzeczywista miąższość zakumulowanych mad wynosi 1,15 m (ryc. 2A), a w drugim 2,0 m (ryc. 2B). Na tej podstawie należy stwierdzić, że wartości tempa akumulacji mad określone na podstawie badań izotopów promieniotwórczych można odnosić tylko do górnych części profili, dla których zostały obliczone. Rzeczywiste średnie tempo roczne akumulacji mad w całym profilu Tyn 1 było z pewnością większe, natomiast w profilu Tyn 2 znacznie mniejsze od oszacowanego na podstawie badań aktywności izotopów cezu i ołowiu. Zdaniem Czajki (2007) akumulacja aluwiów przykorytowych w poszczególnych latach zmienia się od $1 \mathrm{~cm}$ do ponad $30 \mathrm{~cm}$. Określenie średniego tempa depozycji ma więc charakter czysto poglądowy i nie odzwierciedla rzeczywistego procesu akumulacji badanych mad (Froehlich, Walling, 2006).

Warto podkreślić fakt, że w przypowierzchniowej warstwie aluwiów pozakorytowych, w której następuje spadek aktywności cezu powyżej piku podwyższonej aktywności związanego z katastrofą czarnobylską, obserwuje się także spadek koncentracji metali (ryc. 5). Zjawisko to należy wiązać ze spadkiem produkcji przemysłowej i polityką proekologiczną prowadzoną w okresie po transformacji ustrojowej w latach 90. XX w.

Stopień zanieczyszczenia metalami ciężkimi badanych aluwiów określono, stosując indeks geoakumulacji Müllera (wg Förstera 1989; Bojakowskiej 1995). Wartości tego wskaźnika wyznaczone dla koncentracji $\mathrm{Cr}, \mathrm{Cu}, \mathrm{Ni}, \mathrm{Pb}, \mathrm{Zn}$ i Cd w badanych 
aluwiach przyporządkowano do czterech klas: 0-1 - charakteryzują osady naturalne, 2-3-umiarkowanie zanieczyszczone, 4-5 - wysoko zanieczyszczone, 6- ponadnormatywnie zanieczyszczone. Wyniki tej klasyfikacji dla osadów w trzech profilach umieszczono na ryc. 7. Spośród analizowanych osadów najbardziej zanieczyszczone są aluwia pobrane z profilu Tyn 1 . W przypadku kadmu i miedzi stwierdzono tu koncentrację ponad normę. Wysokie zanieczyszczenie tymi pierwiastkami stwierdzono także w profilu Tyn 2. Natomiast ich koncentracja w profilu Tyn 3 utrzymuje się na poziomie umiarkowanym. W znacznej części profili Tyn 2 i 3 koncentracja niklu, ołowiu, chromu i cynku utrzymuje się na poziomie tła geologicznego, obliczonego dla środkowo-wschodniej części Polski przez Bojakowską (1995) oraz mad pobranych $z$ den dolin rzecznych na terenie Niemiec (Fauth i in. 1995).

W porównaniu z badaniami koncentracji metali ciężkich, przeprowadzonymi przez Helios-Rybicką (1983), maksymalna koncentracja metali ciężkich w profilu Tyn 1 jest zwykle niższa niż w określanej przez nią „,madzie przemysłowej”: Cd ponad 5-krotnie, Zn, Pb i Ni około 2-krotnie. Natomiast stężenia maksymalne Cu i Cr są podobne do siebie. Z kolei w stosunku do zaobserwowanych przez Macklina i Klimka (1992) maksymalne koncentracje cynku są prawie 2- krotnie wyższe, a ołowiu i kadmu prawie 2-krotnie niższe w aluwiach wyróżnionego przez nich drugiego poziomu równiny zalewowej niż w madach profilu Tyn 1. Różnice w stwierdzonych wartościach zanieczyszczenia aluwiów pozakorytowych Wisły metalami ciężkimi mogą wynikać z różnic w lokalnych warunkach sedymentacji, różnych metod pomiarów koncentracji i migracji pierwiastków śladowych z wodami gruntowymi po spiętrzeniu wody w korycie Wisły w 1990 r. na stopniu Kościuszko.

Podobnie do rozkładu stężenia metali ciężkich zaobserwowanego w profilu Tyn 1 przebiega rozkład pionowy koncentracji Zn, Pb i Cd zbadany przez Macklina i Klimka (1992). Stwierdzili oni, że największa koncentracja pierwiastków występuje na głębokości około $50 \mathrm{~cm}$ pod powierzchnią równiny zalewowej i jest związana z rozwojem przemysłu oraz hutnictwa cynku i ołowiu na Górnym Śląsku w latach 50.-60. ubiegłego wieku. Takie same przyczyny maksymalnej koncentracji metali ciężkich w madach wiślanych w Kotlinie Oświęcimskiej przyjęli Ciszewski i Kaczka (2009). Różnica w zaobserwowanym rozkładzie koncentracji pierwiastków śladowych w profilu Tyn 1 a zbadanym przez Macklina i Klimka (1992) w aluwiach zdeponowanych na najniższym poziomie zalewowym polega na tym, że nie stwierdzają oni ponownego wzrostu stężenia w przypowierzchniowej warstwie mady. Natomiast w wynikach badań Ciszewskiego i Kaczki (2009) wzrost taki występuje w poziomie najwyższej aktywności ${ }^{137} \mathrm{Cs}$, a następnie stężenie metali ciężkich maleje ku powierzchni. Ze względu na ścisły związek wzrostu koncentracji pierwiastków śladowych z maksimum koncentracji radiocezu należy stwierdzić, że okres wzrostu przypada na początek lat 80. XX w., a jego przyczyną jest niekontrolowany pod względem emisji i oczyszczania ścieków komunalnych i przemysłowych rozwój gospodarki w tym okresie. 
Mając na uwadze zaobserwowany w profilu Tyn 1 oraz w badaniach Macklina i Klimka (1992) oraz Ciszewskiego i Kaczki (2009) istotny wzrost skażenia mad wiślanych związany z rozwojem przemysłu w latach 50., można przypuszczać, że znaczący wzrost koncentracji metali ciężkich w profilu Tyn 2 na głębokości $20 \mathrm{~cm}$ oraz na głębokości $30 \mathrm{~cm}$ w profilu Tyn 3 nastąpił także w latach 50.-60. ubiegłego wieku.

\section{Podsumowanie}

Z przedstawionych wyników badań wynika, że mady w przełomie Wisły pomiędzy Tyńcem i Piekarami były deponowane na wyższych poziomach równiny zalewowej od co najmniej 3 tys. lat. Natomiast na współcześnie modelowanym przez procesy fluwialne, najniższym poziomie, w obrębie pasa meandrowego, od co najmniej 200 lat. Chociaż typowa dla sedymentacji pozakorytowej rytmiczna sekwencja warstw, charakterystyczna dla aluwiów pozakorytowych, jest w nich słabo czytelna, to zarówno pod względem cech litofacjalnych, jak i uziarnienia są to osady różnorodne. Zróżnicowanie to z wynika głównie ze zmiennych warunków przepływów pozakorytowych (Szmańda 2011). W aluwiach współczesnego wału korytowego zostały zapisane przepływy o największej energii, a w drobnoklastycznych osadach basenu powodziowego przepływy o najmniejszej prędkości. Chociaż zróżnicowanie mad zdeponowanych w basenie powodziowym na drugim poziomie jest najmniejsze, to prawdopodobnie w nich został zapisany cykliczny przebieg fal powodziowych w postaci mułkowego rytmitu powodziowego. Mimo dużego zróżnicowania uziarnienia badanych aluwiów pozakorytowych ustalono, że powstawały one głównie w warunkach dolnego ustroju przepływu wody. Wyjątek stanowią warstwy piasków żwirowych i diamiktonu powodziowego, których obecność w profilach może świadczyć nie tylko o wysokoenergetycznych przepływach pozakorytowych, w warunkach górnego ustroju przepływu, ale także o transporcie materiału klastycznego w płynach wysokoskoncentrowanych, a nawet płynach o charakterze plastyczno-lepkim typu prądów zawiesinowych.

Zmierzona w analizowanych profilach aktywność izotopów ${ }^{137} \mathrm{Cs}$ i ${ }^{210} \mathrm{~Pb}$ stała się podstawą do oszacowania tempa sedymentacji aluwiów w zakresie $2-4 \mathrm{~mm} / \mathrm{rok}$. Jednak tak oszacowane tempo akumulacji mad można odnosić tylko do stropowych części profili. Aktywność cezu pozwoliła także na ustalenie czasu depozycji aluwiów w górnych częściach profili, na pierwszym i drugim poziomie równiny zalewowej, co umożliwiło określenie czasu spadku koncentracji metali ciężkich i przyjęcie jako jego przyczyny kryzysu gospodarczego i wdrożenia polityki proekologicznej w latach 90. XX w. Skorelowanie niższego piku aktywności tego radionuklidu ze znacznym podwyższeniem koncentracji pierwiastków śladowych było pomocne w określeniu 
czasu depozycji mad w stropie drugiego poziomu zalewowego na 2. połowę XX w., okresu rozwoju przemysłu i urbanizacji na Górnym Śląsku.

Zaobserwowana w madach najniższego poziomu zalewowego wysoka aktywność pierwiastków śladowych świadczy o ich bardzo dużym zanieczyszczeniu, w przypadku niektórych metali na poziomie ponadnormatywnym. Ponadto stwierdzona pionowa zmienność ich koncentracji umożliwiła ustalenie czasu depozycji mad na głębokości 0,5 m poniżej poziomu najniższej terasy na lata 50.-60. XX w., poprzez powiązanie najwyższej koncentracji pierwiastków śladowych z najintensywniejszą produkcją przemysłową na Górnym Śląsku.

\section{Podziękowania}

Autorzy artykułu dziękują Recenzentom za uwagi, komentarze i wskazówki pomocne przy redakcji tekstu.

\section{Literatura}

Alexandrowicz S., 1960, Budowa geologiczna okolic Tyńca, Biuletyn Instytutu Geologii, 152, 5-93.

Bojakowska I., 1995, Wpływ odprowadzania ścieków na akumulację metali cięzkich w osadach wybranych rzek Polski, Instrukcje i Metody Badań Geologicznych, 55, Warszawa.

Ciszewski D., Czajka A., 2009, Akumulacja osadow na równinach zalewowych rzek silnie smienionych antropogenicznie: górna Wista i Odra, Przegląd Geologiczny, 57 (7), 576-583.

Czajka A., 2007, Środowisko sedymentacji osadów przykorytowych rzek uregulowanych na przykładzie górnej Odry i górnej Wisty, Wyd. UOE, Katowice.

Fauth H., Hindel R., Siewers U., Zimmer J., 1995, Geochemischer Atlas Bundesrepublik Deutschland Bundesantalt fur Geowissenchaften und Rohstoffe (BGR), Hannover.

Förstner U., 1989, Contaminated sediments, Springer Verlag, Berlin.

Froehlich W., Walling D.E., 2006, The use of 137Cs and 210Pbex to investigate sedimentsources and overbank sedimentation rates in the Teesta River basin, Sikkim Himalaya, India, Sediment Dynamics and the Hydromorphology of Fluvial Systems (Proceedings of a symposium held in Dundee, UK, July 2006), IAHS Publ. 306, 380-388.

Gębica P., 2004, Præebieg akumulacji ræecznej w górnym Vistulianie w Kotlinie Sandomierskiej, Prace Geograficzne, IGiPZ PAN, 193, 7-226.

Gilewska S., 1972, Wy:zny Ślqasko-Matopolskie [w:] M. Klimaszewski (red.), Geomorfologia Polski, tom 1, Góry $i$ wyżyny, PWN, Warszawa, 232-279.

He Q., Walling D.E., 1996, Use of fallout Pb-210 measurements to investigate longer-term rates and patterns of overbank sediment deposition on the floodplains of lowland rivers, Earth Surface Processes and Landforms, 21, 141-154.

Helios-Rybicka E., 1983, The content and chemical forms of heavy metals in the sediments of the Cracow area - the role of clay minerals, Environmental Technology Letters, 4, 515-520. 
Klimaszewski M., 1972, Podziat geomorfologiczny Polski Potudniowej [w:] M. Klimaszewski (red.), Geomorfologia Polski, tom 1, Góry i wyżny, PWN, Warszawa, 5-17.

Klimek K., Zawilińska L., 1985, Trace elements in alluvia of the upper Vistula as indicators of palaeohydrology, Earth Surface Processes and Landforms, 10, 273-280.

Korobova E., Linnik V., Chizhikova N., 2008, The history of the Chernobyl Cs-137 contamination of the flood plain soils and its relation to physical and chemical properties of the soil horizons (a case study), Journal of Geochemical Exploration, 96, 236-255.

Kunz A., Pflanz D., Weniger T., Urban B., Krüger F., Chen Y.-G., 2014, Optically stimulated luminescence dating of young fluvial deposits of the Middle Elbe River Flood Plains using different age models, Geochronometria, 41 (1), 36-56.

Łokas E., Wachniew P., Ciszewski D., Owczarek P., Chau N.D., 2010, Simultaneous use of trace metals, 210Pb and 137Cs in floodplain sediments of a lowland river as indicators of anthropogenic impacts, Water Air and Soil Pollution, 207, 57-71.

Macklin M.G., Klimek K., 1992, Dispersal, storage and transformation of metal-contaminated alluvium in the upper Vistula basin, southwest Poland, Applied Geography, 12, 7-30.

Murray A.S., Olley J.M., Caitcheon G.G., 1995, Measurement of equivalent doses in quart: from contemporary water-lain sediments using optically stimulated luminescence, Quaternary Science Reviews, 14, 365-371.

Oczkowski H. L., Przegietka K.R., 1998, TL dating of young aeolian deposits from Kepa Kujawska, Radiation Measurements, 29, 435-439.

Poręba G., Bluszcz A., 2007, Determination of the initial 137Cs fallout on the areas contaminated by Chernobyl fallout, Geochronometria, 26, 35-38.

Preusser F., 1999, Luminescence dating of fluvial sediments and over bank deposits from Gossau, Swit:erland: fine grain dating, Quaternary Science Reviews, 18, 217-222.

Punzet J., 1981, Zmiany w præebiegu stanów wody w dorzeczu górnej Wisty na przestrzeni 100 lat (1971-1970), Folia Geographica, Series Geographica-Physica, 14, 5-28.

Rees A.I., 1966, Some flume experiments with a fine silt, Sedimentology, 6, 209-240.

Rutkowski J., 1986a, Materiat antropogenic nny we wspótcæesnych osadach Wisty pod Tyńcem koto Krakowa, Sprawozdanie z Posiedzenia Komisji Nauk. PAN Oddział w Krakowie 27/1, 231-232.

Rutkowski J., 1986b, The occurrence of carboniferous coal of anthropogenic origin in the contemporaneous Vistula river sediments near Cracow (Southern Poland), Earth Surface Processes and Landforms, 11, 321-326.

Rutkowski J., 1987, Vistula river valley in the Cracow Gate during the Holocene [w:] L. Starkel (red.), Evolution of the Vistula River Valley during the last 15000 year, part II, Geographical Studies, Special Issue 4, IGiPZ PAN, 31-50.

Sly P.G., Thomas R.L., Pelletier B.R., 1983, Interpretation of moment measures derived from water-lain sediments, Sedimentology, 30, 219-233.

Soja R., Mrozek T., 1990, Hydrological characteristics of the Vistula river [w:] L. Starkel (red.), Evolution of the Vistula rivervalley during the last 15000 years, part III, Geographical Studies, Special Issue 5, IGiPZ PAN, 45-62. 
Stach A., 1996, Mo:̇liwości i ograniczenia zastosowania cezu-137 do badan erozji gleb na obsะarze Polski, Instytut Uprawy, Nawożenia i Gleboznawstwa w Puławach, Seria K 2.11, 203-226. Szmańda J.B., 2006, Rytmika powodziowa w alwwiach pozakorytowych Wisty, Drwęcy i Tażyny, Dokumentacja Geograficzna, 32, 266-270.

Szmańda J.B., 2011, Zapis warunków depozycji w uziarnieniu aluwiów pozakorytowych, Landform Analysis, 18, 3-97.

Szmańda J.B., Oczkowski H.L., Przegiętka K.R., 2004, Age of the Vistula river overbank deposits in Toruń, Geochronometria, 23, 35-38.

Teisseyre A.K., 1988, Mady dolin sudeckich. C\%. III: Subarealnie i subakwalnie deponowane osady pozakorytowe w swietle eksperymentu terenowego (1977-1979), Geologia Sudetica, 23 (2), 1-55.

Walling D.E., He Q., 1997, Use of fallout 137Cs in investigation of overbank sediment deposition on river floodplane, Catena, 29, 263-282.

Walling D.E., He Q., 1999, Changing rates of overbank sedimentation on the floodplains of British rivers during the past 100 years [w:] A.G. Brown, T.A. Quine (red.), Fluvial Processes and Environmental Change, John Willey \& Sons Ltd., 207-222.

Wallinga J., 2002, Optically stimulated luminescence dating of fluvial deposits: a review, Boreas, 31, 303-322.

Weckwerth P., Przegiętka K.R., Chruścińska A., Pisarska-Jamroży M., 2013, The relation between optical bleaching and sedimentological features of fluvial deposits in the Torun Basin (Poland), Geological Quarterly, 57, 31-44.

Jacek B. Szmańda

Uniwersytet Pedagogicะny w Krakowie

Instytut Geografii

ul. Podchorą̇ych 2, 30-376 Kraków

jssmanda@up.krakow.pl

Edyta Łokas

Polska Akademia Nauk

Instytut Fizyki Jadrowej im. Henryka

Niewodniczańskiego

ul. Radæikowskiego 152, 31-342 Kraków

Edyta.Lokas@ifj.edu.pl

Przemystaw Wachniew

Akademia Górniczo-Hutnicæa im. Stanistawa

Stasжica w Krakowie

Wydziat Fizyki i Informatyki Stosowanej

ul. Reymonta 19, 30-059 Kraków

wachniew@agh.edu.pl

Anna Michno

Uniwersytet Jagiellonski

Instytut Geografii i Gospodarki Przestrzennej

ul. Gronostajowa 7, 30-387 Kraków

anna.michno@uj.edu.pl
Tomass Kalicki

Uniwersytet Jana Kochanowskiego w Kielcach

Instytut Geografii

ul. Świętokrzyska 15, 25-406 Kielce

tomaszkalicki@ymail.com

Piotr Szwarczewski

Uniwersytet Warszaweski

Wydziat Geografii i Studiow Regionalnych ul. Krakowskie Przedmiescie 30, 00-927 Warsæawa pfswwarc@uw.edu.pl

Krzysztof R. Przegiętka

Uniwersytet Mikołaja Kopernika w Toruniu

Instytut Fizyki

ul. Grudziadzka 5, 87-100 Toruń

przeciu@fizyka.umk.pl

Barbara Radwanek-Bak

Panstwowy Instytut Geologiczny

Oddziat Karpacki

ul. Skræatów 1,30-962 Kraków

barbara.radwanek-bak@pgi.gov.pl 